Article

\title{
Bioassay Directed Isolation, Biological Evaluation and in Silico Studies of New Isolates from Pteris cretica L.
}

\author{
Farooq Saleem 1,2, Rashad Mehmood ${ }^{3}$, Saima Mehar ${ }^{4}$, Muhammad Tahir Javed Khan ${ }^{1}$, \\ Zaheer-ud-Din Khan ${ }^{5}$, Muhammad Ashraf ${ }^{6}$, Muhammad Sajjad Ali ${ }^{7}\left({ }^{\circ}\right.$, Iskandar Abdullah ${ }^{8}(0)$, \\ Matheus Froeyen ${ }^{9}$, Muhammad Usman Mirza ${ }^{7,9}$ (D) and Sarfraz Ahmad ${ }^{8, *}$ (D) \\ 1 Punjab University College of Pharmacy, University of the Punjab, Lahore 54000, Pakistan \\ Faculty of Pharmacy, University of Central Punjab, Lahore 54000, Pakistan \\ Department of Chemistry, University of Education, Vehari Campus, Vehari 61100, Pakistan \\ Department of Chemistry, Sardar Bahadur Khan Women University, Quetta 87300, Pakistan \\ Botany Department, Government College University, Lahore 54000, Pakistan \\ Department of Pharmacy, The Islamia University of Bahawalpur, Bahawalpur 63100, Pakistan \\ Institute of Molecular Biology and Biotechnology, University of Lahore, Lahore 54600, Pakistan \\ Department of Chemistry, Faculty of Science, University of Malaya, Kuala Lumpur 50603, Malaysia \\ 9 Department of Pharmaceutical and Pharmacological Sciences, Rega Institute for Medical Research, \\ Medicinal Chemistry, University of Leuven, B-3000 Leuven, Belgium \\ * Correspondence: sarfraz.ahmad@um.edu.my; Tel.: +60-111-633-0590
}

Received: 28 April 2019; Accepted: 24 May 2019; Published: 19 July 2019

\begin{abstract}
Members of genus Pteris have their established role in the traditional herbal medicine system. In the pursuit to identify its biologically active constituents, the specie Pteris cretica L. (P. cretica) was selected for the bioassay-guided isolation. Two new maleates (F9 and CB18) were identified from the chloroform extract and the structures of the isolates were elucidated through their spectroscopic data. The putative targets, that potentially interact with both of these isolates, were identified through reverse docking by using in silico tools PharmMapper and ReverseScreen3D. On the basis of reverse docking results, both isolates were screened for their antioxidant, acetylcholinesterase (AChE) inhibition, $\alpha$-glucosidase (GluE) inhibition and antibacterial activities. Both isolates depicted moderate potential for the selected activities. Furthermore, docking studies of both isolates were also studied to investigate the binding mode with respective targets followed by molecular dynamics simulations and binding free energies. Thereby, the current study embodies the poly-pharmacological potential of $P$. cretica.
\end{abstract}

Keywords: Pteris cretica L.; isolation; molecular docking; neurodegenerative; $\alpha$-glucosidase; 2,2-diphenyl-1-picrylhydrazyl (DPPH)

\section{Introduction}

In the history of human civilization, plants have established a role in treating various ailments thereby reducing morbidity and mortality. With the dawn of modern chromatographic and spectroscopic techniques, this rich source of bioactive compounds was and is being extensively studied for the pursuit of high-end medicines. The small-molecule natural products are secondary metabolites of plants biosynthesized mainly as a defense mechanism against pathogenic microorganisms, insects and herbivores [1,2]. From 1981 to 2014, among small-molecule drugs approved by the FDA, $6 \%$ were unaltered natural products, $26 \%$ natural product derivatives and $27 \%$ synthetic drugs which were either a mimic of natural products or have natural product pharmacophores [3].

The genus Pteris (Pteridaceae) comprises of about 250 species which are widely distributed on all continents excluding Antarctica, with the highest diversity in the tropical and subtropical 
area, particularly including New Zealand, Australia, South Africa, Japan, America, China, and Europe [4]. Various species of Pteris have long been used for the treatment of different human ailments. Pteris cretica L. (P. cretica) is among the most commonly used species of Pteris in Chinese traditional medicines as an antidote, antipyretic, in burn treatment, antimicrobial and wound healing [5]. Sifting of literature shows that sesquiterpenes, ent-kaurane diterpenes and flavonoids have so far been reported from this plant [6]. We have previously reported the antimicrobial and antioxidant potential of this plant [7]. The current study is an extension of our previously published work. Herein, we report the bioassay-directed isolation and identification of two new isolates (F9 and CB18) from two bioactive subfractions of the chloroform extract of P. cretica, along with their structure elucidation, antioxidant, antimicrobial, acetylcholinesterase (AChE) inhibition and $\alpha$-glucosidase inhibition potentials. The screening of potential molecular targets through reverse in silico studies and the stability and binding free energies are also reported here. The results show that the isolates have moderate potentials for all tested biological activities.

Reactive oxygen species (ROS) produced in our normal metabolic pathway are believed to be responsible for various life-threatening disorders such as cardiovascular disorders, cancer, stress, atherosclerosis, Alzheimer's, Parkinson's, etc. [8,9]. The compounds capable of devouring ROS are termed as antioxidants and could be used as a defense against these life-threatening disorders. Alzheimer's is one of the chronic neurodegenerative diseases characterized by loss of memory, mental abnormality and behavioral instabilities $[10,11]$. Its prognosis involves the upregulation of acetylcholinesterase (AChE) in the brain cell resulting in diminished amounts of acetylcholine neurotransmitter, which in turn alter smooth brain functions including memory loss. This disorder could possibly be controlled by inhibiting the AChE enzyme, and the candidates capable of this property are called AChE inhibitors. Tacrine, donepezil, rivastigmine and galantamine are commonly used as AChE inhibitors.

The overall scheme for discovering molecular targets of phytochemicals have been uplifted by a variety of in silico tools such as the computer-aided drug discovery [12-16], combinatorial chemistry [17-19] and high throughput screening [20-26]. After identifying lead compounds, directly interacting potential targets are identified using the inverse/reverse docking methodology [27,28] on known crystal structures or using various proteomic tools [29,30]. The target identification approaches involving proteomics profiling and pharmacokinetics studies are laborious and time consuming [31]. Therefore, in silico-based target identification methods are always found as the efficient alternative [32]. Within in silico-based target identification of phytochemicals, various tools are used such as computer-aided drug discovery [13,14], combinatorial chemistry [17,18], high throughput screening [25,26] and large-scale reverse pharmacophore mapping strategy. Among various target prediction tools, the large-scale reverse pharmacophore mapping strategy for potential drug targets identification has appeared to be a potential optional technique [28]. The principle of reverse pharmacophore mapping involves the placement of flexible conformation of every small molecule into every pharmacophore model of proteins in the target list [33]. Presently, various in silico tools have been developed that use different target fishing algorithms to execute reverse docking. Few widely used tools include, PharmMapper [33], ReverseScreen3D [34], INVDOCK [35], Tarfisdock [36], idTarget [37], TargetHunter [38]. By utilizing these in silico tools, various studies have been published, including the identification of molecular targets (i.e., proapoptotic, anti-proliferative, anti-inflammatory, anti-invasive, anti-angiogenic) for tea polyphenols [39], saffron bioactive agents [40], essential oils in cardamom [41] and azadirachtin (the principle bioactive compound of neem seeds) [42].

The present study aimed at the isolation and identification of bioactive constituents from $P$. cretica. The potential molecular targets were screened using the reverse docking procedure. To further investigate the binding pose, the molecular dynamic simulations protocol was employed to analyze the stability and binding free energies of docked complexes. Based on in silico outcomes, selected enzyme inhibition assays were performed along with antibacterial activities. The study revealed the 
poly-pharmacological potential of bioactive compounds in P. cretica, responsible for its ethnobotanical uses and biological activities.

\section{Material and Methods}

Column chromatography (CC) was performed on silica gel 60 (70-230 mesh, E. Merck, Darmstadt, Germany). The thin layer chromatography (TLC) was performed on pre-coated silica gel $60 \mathrm{~F}_{254}$ plates (E. Merck, Darmstadt, Germany) and the detection was done at 254 and $330 \mathrm{~nm}$ or by spraying ceric sulfate in $10 \% \mathrm{H}_{2} \mathrm{SO}_{4}$ (heating). High performance liquid chromatography (HPLC) was performed on the Hitachi Primaide HPLC system (Hitachi, Tokyo, Japan) with C18 columns of Thermo Scientific Hypersil GOLD (5 $\mu \mathrm{m}, 175 \AA, 4 \times 250 \mathrm{~mm}$, Waltham, MA, USA), while the large-scale purification was performed with Thermo Scientific Hypersil GOLD (5 $\mu \mathrm{m}, 175 \AA$ A, $21.2 \times 250 \mathrm{~mm})$. Melting points were measured on a Gallenkamp apparatus (Loughborough, England) and optical rotations were measured on a JASCO DIP-360 polarimeter (Jasco, Tokyo, Japan). UV spectra were recorded on a Hitachi UV-3200 spectrophotometer (Hitachi, Tokyo, Japan) while the FTIR spectra were recorded on a Shimadzu FTIR-8900 spectrometer (Shimadzu, Kyoto, Japan). The ${ }^{1} \mathrm{H}$ - and ${ }^{13} \mathrm{C}-\mathrm{NMR}$ spectra were recorded on Bruker AM-400 and AM-500 spectrometers (Bruker BioSpin, Faellanden, Switzerland) in deuterated solvents. The 2D (COSY, HMQC, HMBC) NMR spectra were recorded on the same instruments. The chemical shifts are reported in ppm $(\delta)$, relative to the tetramethylsilane (TMS) as an internal standard and the scalar couplings are reported in Hertz (Hz). Mass spectra (MS and HR-MS) in the FAB (fast atom bombardment) mode on Jeol JMS HX 110 spectrometer (Jeol, Tokyo, Japan) were used with glycerol as matrix and ions were given in $m / z(\%)$. All reagents, solvents and chemicals used were of analytical grade and used without any further purification.

\subsection{Plant Collection and Identification}

P. cretica whole plant was collected from Azad Kashmir, a state of Pakistan, in April 2013 and identified by Prof. Dr. Zaheer-ud-Din Khan, Department of Botany, Govt. College University, Lahore, Pakistan, where a voucher specimen has been deposited in the herbarium (voucher specimen no. is 2142).

\subsection{Extraction and Isolation of Compounds}

The whole plants material of $P$. cretica was shade dried $(1 \mathrm{~kg})$, ground to powder and extracted with chloroform in a Soxhlet apparatus to dark brown residue (34 g). The residue (34 g) was subjected to column chromatography (CC) over silica gel and eluted with hexane-acetone in order to increase polarity to collect 17 fractions. All the obtained fractions were subjected to measure their antioxidant activity and biological potential against five bacteria. The fractions obtained with 6.5:3.5 and 5.5:4.5 hexane-acetone mixtures were found most active against S. aureus and E. coli with 37.66\%, $17.66 \%$ and $38.66 \%, 16.33 \%$ zones of inhibition respectively as compared to the control ampicillin $(100 \%$ and $94.33 \%)$. The fraction obtained with hexane-acetone $(1.8: 1,0.5 \mathrm{~g})$ was further purified by CC over silica gel and eluted with dichloromethane (DCM)-methanol mixture in order to increase polarity to collect thirteen subfractions, and all subfractions were subjected to measure their biological activities. The most bioactive subfraction, which was obtained with DCM-methanol (19:1, 135 mg), was rechromatographed over silica gel and eluted with the same solvent system (DCM-methanol) to collect further several subfractions. The most biological active subfraction which was subjected to p-HPLC using water-acetonitrile $=45: 55$ to $100 \%$ acetonitrile to obtain the pure compound (F9, $5 \mathrm{mg})$.

The second bioactive main fraction, which was obtained with hexane-acetone $(1.2: 1,1.5 \mathrm{~g})$ was subjected to CC over silica gel and eluted with DCM-methanol in increasing order of polarity to collect 12 subfractions. All the subfractions were subjected to biological activity, the subfraction which was obtained with DCM-methanol (5.7:1, $65 \mathrm{mg})$ was the most active subfraction, and subsequently this subfraction was subjected to p-HPLC using water-acetonitrile (2:8) to afford the pure compound (CB18, $6 \mathrm{mg})$. 


\subsubsection{2-Ethyloctyl Maleate (F9)}

Colorless amorphous solid, UV $\lambda_{\max }(\mathrm{MeOH}) \mathrm{nm}(\log \varepsilon): 285(2.1)$. IR $v_{\max }(\mathrm{KBr}) \mathrm{cm}^{-1}: 3334$ (hydroxyl), 2892 br. (carboxylic acid hydroxyl), 1730 (carbonyl), 1653 (conjugated olefin). ${ }^{1} \mathrm{H}-\mathrm{NMR}$ $\left(\mathrm{CDCl}_{3}, 500 \mathrm{MHz}\right) \delta(\mathrm{ppm}): 7.68(1 \mathrm{H}, \mathrm{d}, J=9.0 \mathrm{~Hz}, \mathrm{H}-3), 7.50(1 \mathrm{H}, \mathrm{d}, J=9.0 \mathrm{~Hz}, \mathrm{H}-2), 4.19(2 \mathrm{H}, \mathrm{dd}$, $\left.J=14.5,6.0 \mathrm{~Hz}, \mathrm{H}-1^{\prime}\right), 1.65\left(1 \mathrm{H}, \mathrm{m}, \mathrm{H}-2^{\prime}\right), 1.39$ (2H, m, H-1"'), $1.32\left(2 \mathrm{H}, \mathrm{m}, \mathrm{H}-3^{\prime}\right), 1.30$ (2H, m, H-4'), $1.29\left(4 \mathrm{H}, \mathrm{m}, \mathrm{H}-5^{\prime},-6^{\prime}\right), 1.26\left(2 \mathrm{H}, \mathrm{m}, \mathrm{H}-7^{\prime}\right), 0.90\left(3 \mathrm{H}, \mathrm{t}, J=7.5 \mathrm{~Hz}, \mathrm{H}-2^{\prime \prime}\right), 0.86\left(3 \mathrm{H}, \mathrm{t}, J=7.5 \mathrm{~Hz}, \mathrm{H}-8^{\prime}\right)$, ${ }^{13} \mathrm{C}-\mathrm{NMR}\left(\mathrm{CDCl}_{3}, 150 \mathrm{MHz}\right) \delta$ (ppm): 167.8 (C-1), 130.9 (C-2), $128.8(\mathrm{C}-3), 167.8(\mathrm{C}-4), 68.1\left(\mathrm{C}-1^{\prime}\right), 38.7$ (C-2'), 30.3 (C-3'), 28.9 (C-4'), 29.4 (C-5'), 31.9 (C-6'), 23.0 (C-7'), 14.1 (C-8'), 23.7 (C-1'), $11.0\left(\mathrm{C}-2^{\prime \prime}\right)$. HR-FAB-MS $m / z 257.1747[\mathrm{M}+\mathrm{H}]^{+}$(calcd. for $\mathrm{C}_{14} \mathrm{H}_{25} \mathrm{O}_{4}, 257.1753$ ).

\subsubsection{2-Ethylhexyl Maleate (CB18)}

Colorless amorphous solid, UV $\lambda_{\max }(\mathrm{MeOH}) \mathrm{nm}(\log \varepsilon): 287(2.2)$. IR $v_{\max }(\mathrm{KBr}) \mathrm{cm}^{-1}: 3335$ (hydroxyl), 2898 br. (carboxylic acid hydroxyl), 1732 (carbonyl), 1655 (conjugated olefin). ${ }^{1} \mathrm{H}-\mathrm{NMR}$ $\left(\mathrm{CD}_{3} \mathrm{OD}, 400 \mathrm{MHz}\right) \delta(\mathrm{ppm}): 7.72(1 \mathrm{H}, \mathrm{d}, J=8.8 \mathrm{~Hz}, \mathrm{H}-3), 7.62(1 \mathrm{H}, \mathrm{d}, J=8.8 \mathrm{~Hz}, \mathrm{H}-2), 4.22(2 \mathrm{H}, \mathrm{dd}$, $\left.J=5.6,2.0 \mathrm{~Hz}, \mathrm{H}-1^{\prime}\right), 1.68\left(1 \mathrm{H}, \mathrm{m}, \mathrm{H}-2^{\prime}\right), 1.43\left(2 \mathrm{H}, \mathrm{m}, \mathrm{H}-1^{\prime \prime}\right), 1.36\left(2 \mathrm{H}, \mathrm{m}, \mathrm{H}-3^{\prime}\right), 1.34\left(2 \mathrm{H}, \mathrm{m}, \mathrm{H}-4^{\prime}\right), 1.32$ $\left(2 \mathrm{H}, \mathrm{m}, \mathrm{H}-5^{\prime}\right), 0.94\left(3 \mathrm{H}, \mathrm{t}, J=7.5 \mathrm{~Hz}, \mathrm{H}-6^{\prime}\right), 0.91\left(3 \mathrm{H}, \mathrm{t}, J=7.2 \mathrm{~Hz}, \mathrm{H}-2^{\prime \prime}\right) .{ }^{13} \mathrm{C}-\mathrm{NMR}\left(\mathrm{CD}_{3} \mathrm{OD}, 150 \mathrm{MHz}\right)$ $\delta$ (ppm): 169.4 (C-1), 132.4 (C-2), 129.9 (C-3), 169.4 (C-4), 69.1 (C-1'), $40.2\left(\mathrm{C}-2^{\prime}\right), 31.6\left(\mathrm{C}-3^{\prime}\right), 30.1\left(\mathrm{C}-4^{\prime}\right)$,

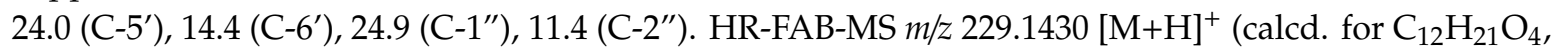
229.1440).

\subsubsection{In Silico Drug Likeness and ADMET Properties of Active Compounds in P. cretica}

In order to check the drug-like potential of active compounds in P. cretica, physicochemical properties were determined from Mcule (https://mcule.com/) [43]. Drug-likeness and the drug score of the compounds, which is based on topological descriptors, fingerprints of molecular drug likeness, structural keys or other properties as $\log P$ and molecular weights were determined from the Molinspiration program (http://www.molinspiration.com/cgi-bin/properties) and Osiris Property Explorer (http://www.organic-chemistry.org/). Detailed ADMET (Absorption, Distribution, Metabolism, Excretion and Toxicity) were predicted from the admetSAR webserver (http://lmmd.ecust.edu.cn: 8000/predict/) [44].

\subsection{Identification of Putative Therapeutic Target}

To find the potential therapeutic targets for active compounds of P. cretica, dual reverse screening approaches were employed by using the ReverseScreen 3D [34] and PharmMapper webservers [33]. ReverseScreen 3D screens the potential targets against biological active small compounds from the updated subsets of co-crystallized ligands present in the Protein Data Bank (PDB). PharmMapper is another reverse screening webserver, which employs pharmacophore-mapping strategy for the identification of potential targets for given small compounds. PharmMapper carries a large, internal database namely PharmTargetDB annotated from all the target information in BindingDB [45], DrugBank [46] and the potential drug target database (PDTD) [47]. Active compounds from P. cretica were submitted to the ReverseScreen 3D and PharmMapper in the default format. The list of potential targets was further investigated to filter out the targets associated to anticancer, antioxidant, anti-inflammatory, and neurodegenerative mechanisms. The high throughput experimental findings of potential targets were manually curated from three different bioassay databases: PubChem Bioassay [48], NPACT [49] and Herbal Ingredients' Targets Database [50]. The list of potential targets identified by the in silico reverse screening method was compared with the target information acquired from three bioassay databases as an experimental evidence. Based on the results, various identified targets such as anti-proliferative, antioxidant and anti-inflammatory targets were sorted out. Alongside the reverse docking, the antibacterial efficacy of the identified compounds was also evaluated by carefully taking into account the potential antibacterial targets after literature review. 


\subsection{Experimental Protocols for Biological Assays}

To validate the therapeutic targets identified by the in silico reverse docking procedure, various biochemical assays were performed.

\subsection{Antibacterial Assay}

The antibacterial potential of isolated compounds F9 and CB18 was measured against Gram-negative Escherichia coli (E. coli), Shigella flexneri (S. flexneri), Pseudomonas aeruginosa (P. aeruginosa) and Klebsiella pneumoniae (K. pneumoniae), and Gram-positive Staphylococcus aureus (S. aureus) bacteria by using a Microplate Alamar Blue Assay (MABA) [51]. The selected bacteria were taken from the Pakistan Council of Scientific and Industrial Research (PCSIR) laboratory, Lahore, Pakistan. Muller Hinton media (MHM) was used for bacterial culturing and $0.5 \mathrm{McFarland}$ turbidity index was maintained for inoculums. MHM $(50 \mu \mathrm{L})$ was inoculated to each well of 96-well microtiter plate under sterile conditions. A volume of $10 \mu \mathrm{l}$ from each test sample was pipetted into all labelled wells excluding control wells. Each well was added with MHM to make a final volume of $200 \mu \mathrm{L}$. A specific bacterial suspension with a volume of $7 \mu \mathrm{L}\left(5 \times 10^{6} \mathrm{cfu} / \mathrm{mL}\right)$ was added to all wells in the plate. To avoid a dehydration issue in bacteria, parafilm was used to cover the microplate and then placed for incubation at $35^{\circ} \mathrm{C}$ for 18 to $20 \mathrm{~h}$. At this phase, the microplate contained a set of samples, standard and a negative control. Next to the incubation period, a multichannel pipette was used to pipette $10 \%$ resazurin (dye) to total culture volume into each well. Now the microplate was mixed with a speed of $80 \mathrm{rpm}$ in a shaking incubator for 2 to $3 \mathrm{~h}$. During the blending process, it was ensured that the parafilm remained attached with the plates. The change in color from blue to pink was the assessment of bacterial growth (viability).

The diminution in blue color concentration was measured with the ELISA reader at $570 \mathrm{~nm}$ and $600 \mathrm{~nm}$ wavelengths. The percentage inhibition was calculated with the following formula and repeated thrice to find the mean inhibition and standard deviation.

$$
\% \text { Difference }=\frac{\left(\varepsilon_{\mathrm{ox}}\right) \lambda_{2} \mathrm{~A} \lambda_{1}-\left(\varepsilon_{\mathrm{ox}}\right) \lambda_{1} \mathrm{~A} \lambda_{2} \text { of test agent dilution }}{\left(\varepsilon_{\mathrm{ox}}\right) \lambda_{1} \AA \lambda_{2}-\left(\varepsilon_{\mathrm{ox}}\right) \lambda_{2} \AA \lambda_{1} \text { of untreated positive growth control }} \times 100
$$

where, $\varepsilon_{\mathrm{ox}}$ is the molar extinction coefficient of Alamar blue oxidized form (blue), A is the absorbance of the test well, $\AA$ is the absorbance of the positive growth control well, $\lambda_{1}$ is the wavelength at $570 \mathrm{~nm}$ and $\lambda_{2}$ is the wavelength at $600 \mathrm{~nm}$.

\subsection{Antioxidant Activity}

Stock solutions of test compounds F9 and CB18 and standard vitamin C were prepared in ethanol at a concentration of $(1 \mathrm{mg} / \mathrm{mL})$. Each well of 96-well microtiter plate was loaded with $50 \mu \mathrm{L}$ of ethanol. The serial dilutions $(128,64,32,16,8,4,2,1,0.5,0.25,0.125 \mu \mathrm{g} / \mathrm{mL})$ were prepared by using $50 \mu \mathrm{L}$ of stock solution. The ethanolic solution of DPPH $(150 \mu \mathrm{L}, 0.05 \mathrm{mM})$ was added to each well. Control wells contained $50 \mu \mathrm{L}$ ethanol and $150 \mu \mathrm{L}$ DPPH solution. The plate was incubated for $30 \mathrm{~min}$ in the dark and the absorbance was read at $517 \mathrm{~nm}$. The antioxidant activity was expressed as the percentage radical scavenging activity (\%RSA) and calculated by using the following expression.

$$
\% \text { RSA }=(\mathrm{Ac}-\mathrm{As}) / \mathrm{Ac} \times 100
$$

where, Ac and As are the absorbance of control and sample, respectively. The experiment was repeated thrice to find the mean $\% R S A \pm$ standard deviation and $I C_{50}$ was calculated by plotting the log of concentration against the mean \%RSA. 


\subsection{Acetylcholinesterase (AChE) Inhibition Activity}

The AChE inhibition potential of isolates was investigated according to the reported procedure with slight modifications [52]. The methanolic solution of the test compound or standard (Eserine) $(10 \mu \mathrm{L}, 0.5 \mathrm{mM})$ was added to 96 -well plates containing $60 \mu \mathrm{L}$ phosphate buffer $(\mathrm{pH}=7.7,50 \mathrm{mM})$. Control wells contained $60 \mu \mathrm{L}$ phosphate buffer and $10 \mu \mathrm{L}$ methanol. This was followed by loading $10 \mu \mathrm{L}$ enzyme ( 0.005 units for AChE) to each well. The wells contents were shaken and the absorbance at $405 \mathrm{~nm}$ was measured. The plate was incubated at $37^{\circ} \mathrm{C}$ for $10 \mathrm{~min}$ and the substrate (acetylthiocholine iodide) $(10 \mu \mathrm{L}, 0.5 \mathrm{mM})$ and 5, 5-Dithio-bis-(2-Nitrobenzoic Acid) $(10 \mu \mathrm{L}, 0.5 \mathrm{mM})$ were added to each well. The plate was incubated for $15 \mathrm{~min}$ at $37^{\circ} \mathrm{C}$ and the absorbance was measured at $405 \mathrm{~nm}$ using a 96-well plate reader. The test was repeated in triplicate and the percentage inhibition was calculated by following the formula.

$$
\% \text { Inhibition }=(\mathrm{Ac}-\mathrm{As}) / \mathrm{Ac} \times 100
$$

\section{8. $\alpha$-Glucosidase (GluE) Inhibition Assay}

$\alpha$-Glucosidase (GluE) inhibition assay was carried out with slight modifications in the method performed by Chapdelaine [53]. The wells of the 96-well microtiter plate were loaded with $70 \mu \mathrm{L}$ phosphate buffer saline $(50 \mathrm{mM}, \mathrm{pH}=6.8)$ and the test samples or Acarbose as standard $(10 \mu \mathrm{L}$, $0.5 \mathrm{mM})$. The control wells contained $70 \mu \mathrm{L}$ phosphate buffer and $10 \mu \mathrm{L}$ methanol. A volume of $10 \mu \mathrm{L}$ GluE enzyme ( 0.057 units) was pipetted into each well followed by proper mixing. After 15 min of pre-incubation period (at $37^{\circ} \mathrm{C}$ ), the absorbance was recorded at $400 \mathrm{~nm}$. For the initiation of reaction, $10 \mu \mathrm{L}$ of p-nitrophenyl glucopyranoside $(0.5 \mathrm{mM})$ was added as the substrate. The plate was incubated for $30 \mathrm{~min}$ at $37^{\circ} \mathrm{C}$ before measuring the absorbance at $400 \mathrm{~nm}$. The percentage inhibition was calculated by the same following formula and the experiment was repeated in triplicate to find the mean and standard deviation.

$$
\% \text { Inhibition }=(\mathrm{Ac}-\mathrm{As}) / \mathrm{Ac} \times 100
$$

\subsection{Molecular Docking of Potential Targets with Bioactive Compounds}

To investigate the binding mode and molecular interactions of investigated compounds with therapeutic targets as identified with the experimental procedure, molecular docking studies was employed using Autodock Vina with default setting and parameters [54]. The X-ray determined crystallographic 3D structures of identified potential targets including AChE (PDB ID: 4BDT), based on the mechanism involved in neurodegeneration were retrieved from PDB with a good resolution and R-free factor [55] while Saccharomyces cerevisiae $\alpha$-glucosidase enzyme was modeled using Saccharomyces cerevisiae isomaltase (PDB ID: 3AJ7, Identity: $72.4 \%$ ) as a template due to the unavailability of crystal structure. SWISS-MODEL [56] was utilized for homology modeling and the model was refined through $20 \mathrm{~ns}$ MD simulations. For antimicrobial targets, an extensive literature review was performed and the dihydropteroate synthase (DHPS) from Escherichia coli, and dihydrofolate reductase (DHFR) from Staphylococcus aureus were selected for docking studies and there the corresponding PDB IDs were 5U10 (E. coli DHPS complex with pteroic acid) [57] and 4LAE (S. aureus DHFR complex with 7-(Benzimidazol-1-yl)-2,4-diaminoquinazolines) (PDB ID: 4LAE) [58].

For the structure preparation, co-crystalized ligands were separated from the corresponding proteins and re-docked again to calculate the RMSD of docked and co-crystalized ligand for reliability of the AutoDock Vina protocol [54]. The overall protocol of the protein preparation, minimization and optimization has been distinctively described elsewhere [59-61]. The molecular structures of potent bioactive compounds $\mathbf{F 9}$ and $\mathbf{C B 1 8}$ were generated from the ACD/ChemSketch Freeware, the software was employed to design the 2D structure and OpenBabel was used to convert 2D to 3D structure. AutoDock Tools were used to merge non-polar hydrogens, add Gasteiger charges and rotatable bonds adjustments. The docked complexes were investigated for molecular interactions utilizing UCSF Chimera v10 [62]. 


\subsection{Molecular Dynamics Simulations and Binding Free Energy Calculations}

To understand the dynamic behavior with respect to time (nanoseconds, ns), the best-docked complexes from molecular docking studies were executed through 20 ns MD simulations. All MD simulations were executed using the AMBER 16 package [63]. We implemented the same MD simulation protocol as described in our previous study [64]. The CPPTRAJ module of AMBER 16 [65] was used for the trajectory analysis.

To further explore the binding free energy calculations between selected proteins with bioactive compounds separately. A total of 500 snapshots were extracted from the whole trajectory for binding free energy calculations using the molecular mechanics-generalized Born surface area (MMGBSA) method. MMGBSA calculations were performed using the mmpbsa module of AMBER 16 package. The details of the MMGBSA method have been explained elsewhere [66,67]. The MMGBSA total energy $\left(\Delta \mathrm{G}_{\mathrm{tol}}\right)$ was divided into molecular mechanics $\left(\Delta \mathrm{E}_{\mathrm{MM}}\right)$ and solvation energy $\left(\Delta \mathrm{G}_{\mathrm{sol}}\right)$ contributions. $\Delta \mathrm{E}_{\mathrm{MM}}$ is further divided into electrostatic energy contributions $\left(\Delta \mathrm{E}_{\text {ele }}\right)$ and van der Waals $\left(\Delta \mathrm{E}_{\mathrm{vdw}}\right)$ while the solvation energy is divided into polar $\left(\Delta G_{p}\right)$ and nonpolar $\left(\Delta G_{n p}\right)$ contributions.

$$
\begin{gathered}
\Delta \mathrm{E}_{\mathrm{MM}}=\Delta \mathrm{E}_{\text {int }}+\Delta \mathrm{E}_{\text {ele }}+\Delta \mathrm{E}_{\mathrm{vdw}} \\
\Delta \mathrm{G}_{\mathrm{sol}}=\Delta \mathrm{G}_{\mathrm{p}}+\Delta \mathrm{G}_{\mathrm{np}} \\
\Delta \mathrm{G}_{\mathrm{tol}}=\Delta \mathrm{E}_{\mathrm{MM}}+\Delta \mathrm{G}_{\mathrm{sol}}
\end{gathered}
$$

\section{Results and Discussion}

In our previous study on P. cretica, n-hexane, chloroform and ethanol extracts of the whole plant were screened for antimicrobial and antioxidant activities. The chloroform extract was found the most active among all studied extracts [7]. The current study was commenced to isolate the active ingredients from the chloroform extract. The shade dried whole plant was ground and extracted with chloroform using the Soxhlet extractor. The crude extract was subjected to repeated column chromatography steps, each followed by biological activates of fractions in a bioassay-guided manner to identify the most active fractions. After column chromatography steps, most active fractions were subjected to the reverse phase HPLC to isolate the pure ingredients.

Compound F9 was obtained as a white amorphous powder. The UV spectrum showed the absorption bands at $285 \mathrm{~nm}$, while the IR spectrum exhibited absorptions for the presence of hydroxyl $\left(3334 \mathrm{~cm}^{-1}\right)$, carboxylic acid hydroxyl $\left(2892 \mathrm{br} . \mathrm{cm}^{-1}\right)$, carbonyl $\left(1732 \mathrm{~cm}^{-1}\right)$, and olefinic $\left(1655 \mathrm{~cm}^{-1}\right)$ moieties. The molecular formula was deduced as $\mathrm{C}_{14} \mathrm{H}_{25} \mathrm{O}_{4}$ by high resolution FAB-MS (fast atom bombardment-mass spectrum), which showed the pseudo molecular ion $[\mathrm{M}+\mathrm{H}]^{+}$peak at $m / z 257.1747$. Two downfield doublets of ${ }^{1} \mathrm{H}-\mathrm{NMR}$ spectrum of $\mathbf{F 9}$ (Table 1) of olefinic protons at $\delta 7.68$ and 7.50 with coupling constant $9.0 \mathrm{~Hz}$ revealed the presence of olefinic bond having cis geometry. A methylene proton signal at $\delta 4.19(\mathrm{dd}, J=14.5,6.0 \mathrm{~Hz})$ showed its connectivity with oxygen and methine multiplet at $\delta 1.65(1 \mathrm{H}, \mathrm{m})$ in COSY. The high frequency region was a characteristic of hydrocarbon chain methylenes within the range of $\delta 1.29-139(12 \mathrm{H})$ and the presence of two terminal methyl groups was revealed by two triplets at $\delta 0.90(\mathrm{t}, J=7.5 \mathrm{~Hz})$ and $0.86(\mathrm{t}, J=7.5 \mathrm{~Hz})$, which indicated the presence of a branch in the hydrocarbon chain. ${ }^{13} \mathrm{C}-\mathrm{NMR}$ (BB and DEPT) spectra showed the carbonyl carbons signal at $\delta 167.8$ while the olefinic carbons showed signals at $\delta 130.9$ and 128.9. The oxygenated methylene carbon was observed at $\delta 68.1$ whereas a methine carbon showed the signal at $\delta 38.1$. The methylene carbons of the hydrocarbon chain were resonated in the range of $\delta 23.0-31.9$ with the two terminal methyl signals at $\delta 14.1$ and 11.0. 
Table 1. Potential therapeutic targets of isolates F9 and CB18 identified by PharmMapper and ReverseScreen3D.

\begin{tabular}{|c|c|c|c|c|c|}
\hline \multirow{2}{*}{ Drug Target Proteins } & \multicolumn{2}{|c|}{ F9 } & \multicolumn{2}{|c|}{ CB18 } & \multirow{2}{*}{$\begin{array}{l}\text { Experimental } \\
\text { Evidence }\end{array}$} \\
\hline & Target Hit & Fit Score & Target Hit & Fit Score & \\
\hline EGFR & $\checkmark$ & 3.48 & $\checkmark$ & 4.96 & PubChem Bioassay \\
\hline Estrogen receptor beta & n.a & n.a & $\checkmark$ & 3.996 & NPACT \\
\hline Cytochrome P450 2C9 & $\checkmark$ & 4.22 & n.a & n.a & NPACT \\
\hline Acetylcholinesterase (AChE) & $\checkmark$ & 4.52 & $\checkmark$ & 4.3 & PubChem Bioassay \\
\hline TGF-beta receptor type-1 & $\checkmark$ & 3.75 & n.a & n.a & Drug Bank \\
\hline phosphodiesterase-5 (PD-5) & $\checkmark$ & 4.72 & n.a & n.a & Drug Bank \\
\hline Cell dependent kinase 2 & n.a & n.a & $\checkmark$ & 2.65 & PubChem Bioassay \\
\hline Caspase 3 & $\checkmark$ & 4.67 & $\checkmark$ & 5.02 & NPACT \\
\hline Deoxycytidine kinase & $\checkmark$ & 2.66 & n.a & n.a & Drug Bank \\
\hline human carboxylesterase (hCE-1) & $\checkmark$ & 3.87 & n.a & n.a & PubChem Bioassay \\
\hline $\begin{array}{l}\text { Fibroblast growth factor receptor } \\
\text { 1, FGFR1 }\end{array}$ & $\checkmark$ & 3.41 & $\checkmark$ & 4.96 & PubChem Bioassay \\
\hline Caspase 7 & $\checkmark$ & 2.41 & n.a & n.a & PubChem Bioassay \\
\hline STAT-3 & $\checkmark$ & 4.93 & $\checkmark$ & 5.39 & PubChem Bioassay \\
\hline Cyclin dependent kinase 6 & $\checkmark$ & 3.81 & $\checkmark$ & 4.34 & Drug Bank \\
\hline Cyclin A2 & n.a & n.a & $\checkmark$ & 3.95 & NPACT \\
\hline p53 & $\checkmark$ & 4.19 & n.a & n.a & Drug Bank \\
\hline $\begin{array}{c}\text { glycogen synthase kinase-3 } \beta \\
\text { (GSK-3 } \beta)\end{array}$ & $\checkmark$ & 4.17 & $\checkmark$ & 3.5 & Drug Bank \\
\hline Apoptosis regulator Bcl-X & $\checkmark$ & 4.88 & n.a & n.a & PubChem Bioassay \\
\hline nitric oxide synthase (NOS) & $\checkmark$ & 3.39 & $\checkmark$ & 3.1 & PubChem Bioassay \\
\hline $\begin{array}{l}\text { vascular endothelial growth } \\
\text { factor, VEGF }\end{array}$ & $\checkmark$ & 3.44 & $\checkmark$ & 4.18 & PubChem Bioassay \\
\hline MAP kinase 14 & $\checkmark$ & 3.63 & n.a & n.a & NPACT \\
\hline Histone deacetylase 8 & $\checkmark$ & 4.26 & $\checkmark$ & 4.21 & PubChem Bioassay \\
\hline Tumor necrosis factor-alpha & $\checkmark$ & 5.34 & $\checkmark$ & 4.97 & PubChem Bioassay \\
\hline $\mathrm{NF}-\mathrm{kB}$ & n.a & n.a & $\checkmark$ & 2.94 & PubChem Bioassay \\
\hline Prothrombin & n.a & n.a & $\checkmark$ & 4.09 & Drug Bank \\
\hline $\begin{array}{c}\text { Ornithine aminotransferase, } \\
\text { mitochondrial }\end{array}$ & $\checkmark$ & 3.78 & $\checkmark$ & 2.97 & PubChem Bioassay \\
\hline Sepiapterin reductase & $\checkmark$ & 4.81 & n.a & n.a & NPACT \\
\hline VEGFR2 & $\checkmark$ & 5.11 & $\checkmark$ & 4.62 & PubChem Bioassay \\
\hline Cyclin dependent kinase 4 & n.a & n.a & $\checkmark$ & 2.54 & Drug Bank \\
\hline cyclooxygenase-2, COX2 & $\checkmark$ & 4.14 & $\checkmark$ & 5.39 & Drug Bank \\
\hline $\begin{array}{l}\text { 3-phosphoinositide-dependent } \\
\text { protein kinase } 1\end{array}$ & n.a & n.a & $\checkmark$ & 4.41 & PubChem Bioassay \\
\hline Beta-secretase 1 & $\checkmark$ & 3.18 & $\checkmark$ & 4.39 & Drug Bank \\
\hline JNK1 & $\checkmark$ & 2.86 & $\checkmark$ & 3.47 & PubChem Bioassay \\
\hline $\begin{array}{c}\text { RAC-alpha } \\
\text { serine/threonine-protein kinase }\end{array}$ & $\checkmark$ & 4.55 & n.a & n.a & PubChem Bioassay \\
\hline Estradio 17 -beta dehydrogenase- 1 & $\checkmark$ & 3.97 & $\checkmark$ & 4.58 & PubChem Bioassay \\
\hline Interleukin- 4 & $\checkmark$ & 2.67 & n.a & n.a & PubChem Bioassay \\
\hline
\end{tabular}

In COSY correlations of F9 (Figure 1), the proton at $\delta 4.19$ (H-1') showed the COSY correlation with the proton at $\delta 1.65\left(\mathrm{H}-2^{\prime}\right)$, which subsequently showed a correlation with the proton at $\delta 1.39\left(\mathrm{H}-1^{\prime \prime}\right)$ and $\delta 1.32\left(\mathrm{H}-3^{\prime}\right)$, revealing the presence of the branch at C-2'. In the HMBC experiment (Figure 1), olefinic protons at $\delta 7.68$ and 7.50 showed ${ }^{2} J$ and ${ }^{3} J$ correlations with the carbonyl at $\delta 167.8$, confirming the presence of olefinic bond adjacent and in conjugation with the carbonyls. The proton at $\delta 4.19\left(\mathrm{H}-1^{\prime}\right)$ showed the ${ }^{3} J$ correlations with carbonyl carbon at $\delta 167.8(\mathrm{C}-4)$, which confirms the presence of ester moiety and connectivity of C-1' with ester oxygen. The proton at $\delta 4.19\left(\mathrm{H}-1^{\prime}\right)$ also showed ${ }^{3} \mathrm{~J}$ with $\delta$ $30.3\left(\mathrm{C}-3^{\prime}\right)$ and $23.7\left(\mathrm{C}-1^{\prime \prime}\right)$, and ${ }^{2} J$ correlation at $\delta 38.1$ (C-2'), and subsequently H-2' ( $\left.\delta 1.65\right)$ showed key ${ }^{2} J$ correlations at $\delta 30.3\left(\mathrm{C}-3^{\prime}\right)$ and $23.7\left(\mathrm{C}-1^{\prime \prime}\right)$ and ${ }^{3} J$ correlation at $\delta$ and $11.0\left(\mathrm{C}-2^{\prime \prime}\right)$, confirming the branch is ethyl group and its connectivity at C-2'. The remaining HMBC correlations illustrated in Figure 1 along with COSY correlations were in complete agreement with the assigned structure of compound $\mathbf{F 9}$ as 2-ethyloctyl maleate (Figure 1). 


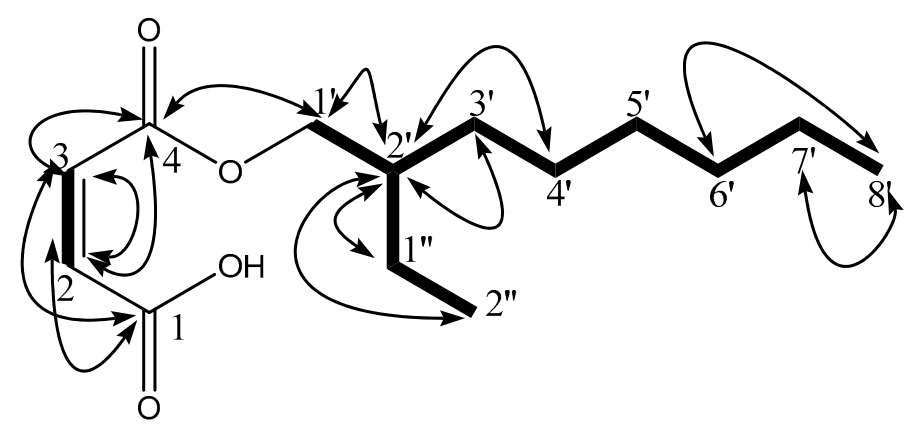

Figure 1. Structure of compound F9 (2-ethyloctyl fumarate) with important ${ }^{1} \mathrm{H}^{1}{ }^{1} \mathrm{H}$ COSY $(\square)$ and ${ }^{1} \mathrm{H}_{-}{ }^{13} \mathrm{C} \mathrm{HMBC}(\longrightarrow)$ correlations.

Compound CB18 was also obtained as a white amorphous powder. The UV and IR spectra were similar to those of compound F9. HR-FAB-MS showed the pseudo molecular ion $[\mathrm{M}+\mathrm{H}]^{+}$peak at $\mathrm{m} / \mathrm{z} 229.1433$ consistent to the molecular formula $\mathrm{C}_{12} \mathrm{H}_{21} \mathrm{O}_{4}$. Compound CB18, therefore, differed from compound $\mathbf{F 9}$ in having two methylene groups less in the hydrocarbon chain, as $[\mathrm{M}+\mathrm{H}]^{+}$peak of compound CB18 was $\mathrm{m} / \mathrm{z} 28$ less to that of compound F9. The ${ }^{1} \mathrm{H}$ and ${ }^{13} \mathrm{C}$ NMR spectra showed common features resemblance to those of compound $\mathbf{F 9}$, allowing to assign the structure of compound CB18 as 2-ethylhexyl maleate (Figure 2).

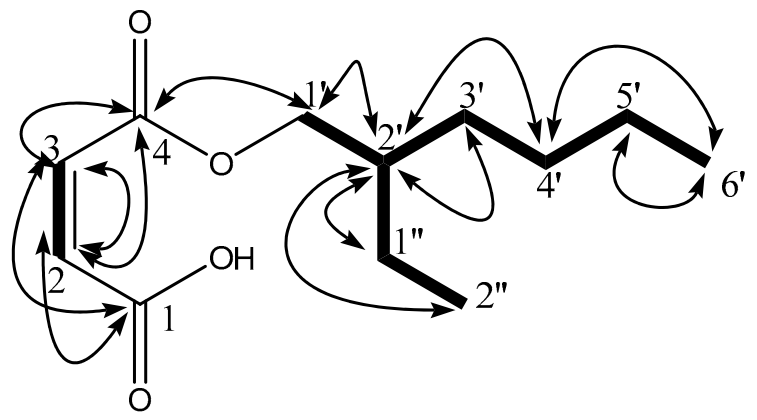

Figure 2. Structure of compound CB18 (2-ethylhexyl fumarate) with important ${ }^{1} \mathrm{H}_{-}{ }^{1} \mathrm{H} \operatorname{COSY}(\mathbf{m})$ and ${ }^{1} \mathrm{H}^{-13} \mathrm{C}$ HMBC $(\longrightarrow)$ correlations.

\subsection{Putative Therapeutic Target for Isolates}

The list of potential top-ranked targets predicted from PharmMapper and ReverseScreen3D were tabulated in Table 1. Most of these targets are associated to anticancer, anti-inflammatory and neurodegenerative mechanisms as demonstrated in proceeding sections. The pharmacokinetics/ADMET estimations of both bioactive compounds are tabulated in Supplementary Table S1.

\subsection{Antiproliferative Targets}

The process of growth and differentiation is under tight regulation, controlled by growth factors and their receptors. Abnormal growth and development may result as a consequence of slight variations in the regulation of expression of the molecules associated, causing malignant transformation. An increase in the expression level of growth factors for instance, transforming growth factor- $\alpha$ (TGF- $\alpha$ ), can lead to non-cancerous disease, one such example is psoriasis. Anticancer studies have demonstrated a significant role of growth factors regarding anticancer activity [68]. Proliferation of a cancerous cell has portrayed an over-expression of the epidermal growth factor receptor (EGFR) as a prominent factor [68-70]. Two distinct signaling pathways regulate the apoptotic process which forms a loop-structure after their merger as a result of the effector molecule, Caspase 3 activation [71]. Reverse Screening has helped us to figure out various growth factors that can act as potential targets for bioactive compounds identified in P. cretica. The basic fibroblast growth factor receptor 1 and placental 
growth, epidermal growth factor receptor and VEGFR2 were estimated to bind with both compounds. The anti-angiogenesis potential of P. cretica might be central to the binding to these growth factors. The proapoptotic activity has been linked with these bioactive compounds, which bind to BCL-XL, Caspase 3 and Caspase 7 for further activation. Cyclins play a key role in different phases of a cell cycle. Three types of cyclins (cyclin D1, cyclin D2, cyclin D3) bind to CDK4 and to CDK6 and CDK-cyclin D complexes to regulate the entry in the G1 phase [72,73]. This study identified that the proliferation inhibition can be brought about by targeting Cyclin-A2 and cyclin dependent kinases 2 causing G1 cell cycle arrest through CB18 and F9. This process promotes apoptotic cell death and hence, estimated the onco-protective potential of P. cretica. As tabulated in Table 1, a set of other targets including MAP kinase 14, Estrogen receptor Beta, p53, revealed CB18 and F9 of significant importance with respect to cancer-preventive potential of $P$. cretica.

\subsection{Antioxidant and Antiinflammatory Targets}

Studies centered upon carcinogenesis have indicated inflammation to be of prime importance in the process, involving tumor initiation, promotion and its progression. Acute inflammation though observed to play a significant role in defense response, cancer has been found to be caused by chronic inflammation [74]. For their role in the inhibition of proliferation, angiogenesis, invasion and metastasis, pro-inflammatory gene products have been in the spotlight over the last two decades [75]. Studies have demonstrated that the progression of various forms of cancer involves key components of inflammatory pathways such as cytokines, signal transducer and activator of transcription-3 (STAT-3), prostaglandins, free radicals, vascular endothelial growth factor (VEGF), NF- $\mathrm{kB}$, cyclooxygenase-2 (COX-2) and inducible nitric oxide synthase (iNOS) [76,77]. In the progression of inflammation, in controlling the factors that deal with the immune cells, the tumor necrosis factor (TNF) has a significant contribution, which was estimated as a potential target identified for both bioactive compounds of $P$. cretica. The current reverse screening protocol, has revealed many anti-inflammatory targets including Tumor necrosis factor, Estradio 17-beta dehydrogenase-1, cyclooxygenase-2, Interleukin- 4 and VEGFR that have the potential to bind with CB18 and F9, key bioactive compounds of P. cretica.

\subsection{Neurodegenerative Mechanism}

Neurodegeneration being multi-factorial represents a complex pathogenesis. One of the neurodegenerative disorders, Alzheimer's disease (AD), is characterized by the development of plaques formed by the aggregation of beta-amyloid $(\mathrm{A} \beta)$ peptide, responsible for causing neuronal death [78]. Amyloid precursor protein (APP) that undergoes a cleavage by $\beta$-secretase, is an attractive target for developing potent inhibitors. Furthermore, secretases that cleave amyloid precursor protein are thought to be potential targets for inhibiting APP cleavage [79]. It has been hypothesized that $A \beta$ protein accumulates inside the brain causing neurons to die. Hence, the inhibition of $A \beta$ aggregation and deposition by inhibiting COX 1 and 2 is considered to play a significant role in treating neuronal damage $[80,81]$. Neurofibrillary tangles formed as result of Tau protein phosphorylation have been found to contribute towards progression of neurodegeneration through paired helical filament-tau (PHF-tau) production. It has been observed that dephosphorylation caused by kinases:

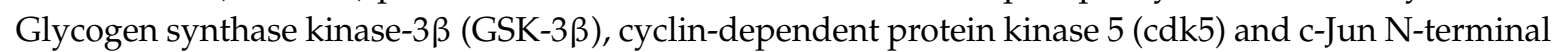
kinases (JNKs), alleviates cognitive decline [82,83]. Cholinesterases, specifically, acetylcholinesterase (AChE) and butyrylcholinesterase (BuChE) are responsible for the catalytic hydrolysis of important neurotransmitter acetylcholine and butyrylcholine, respectively [84]. Moreover, the inhibition of human carboxylesterase (hCE-1) being similar in structure to cholinesterases (ChE) is also considered as an effective strategy [85]. Oxidative stress has been linked to the neuronal cell death since long. The induction of nitric oxide (NO) produced by nitric oxide synthase (NOS) has been found to play a role in oxidative damage linked to neurodegeneration [86]. Pro-inflammatory cytokines have been found responsible for neuroinflammation leading to neurodegeneration of which TNF- $\alpha$ tops the list [87]. To enhance neuroprotection and cognitive function, the inhibition of phosphodiesterase-5 (PD-5) has 
been found useful [88]. All above-mentioned targets are perfectly identified by bioactive compounds (CB18 and F9) which estimated the neuroprotective potential of P. cretica (Table 1).

\subsection{Biological Activities of Isolates}

Due to experimental and financial constraints, some of the identified targets were selected to evaluate the potential of bioactive compounds from P. cretica against antibacterial and enzymatic inhibition activities. To further estimate the therapeutic potential, other identified targets were taken into account and investigated through molecular modeling studies.

\subsection{Antibacterial Activities}

The antibacterial activities of two isolated compounds were performed against selected bacteria by applying MABA and results have been reported in Table 2 .

Table 2. Antibacterial activities (\% inhibition) of isolates from P. cretica and standard ampicillin at 1 $\mathrm{mg} / \mathrm{mL}$. Each value is average of three repeated experiments \pm standard error (S.E.).

\begin{tabular}{cccccc}
\hline Compounds & E. coli & S. aureus & K. pneumoniae & S. flexneri & P. aeruginosa \\
\hline F9 & $11.33 \pm 0.66$ & $14.00 \pm 0.57$ & - & - & - \\
CB18 & $14.33 \pm 0.33$ & $10.00 \pm 0.00$ & - & - & - \\
Ampicillin & $90.67 \pm 0.66$ & $95.00 \pm 0.00$ & $80.00 \pm 0.00$ & $90.66 \pm 0.66$ & $91.33 \pm 0.88$ \\
\hline
\end{tabular}

For testing of antibacterial activity of isolated compounds, MABA was employed and results have been tabulated in Table 1 . The compounds F9 and CB18 did not demonstrate any activity against $K$. pneumoniae, S. flexneri and P. aeruginosa whilst showed less significant antibacterial activity against $E$. coli (i.e., $11.33 \%$ and $14.33 \%$ ) and S. aureus (i.e., $14 \%$ and $10 \%$ ) as compared to ampicillin at $1 \mathrm{mg} / \mathrm{mL}$.

\subsection{Antioxidant Activities}

Purified compounds were subjected to test their antioxidant potential by the DPPH assay and the results have been tabulated in Table 3 .

Table 3. Antioxidant activity of isolated compounds. Each value represents $I C_{50}$ of average of three repeated experiments \pm standard error (S.E.).

\begin{tabular}{ccc}
\hline Ser. No. & Compounds & DPPH $\left(\right.$ IC $\left._{50}\right) \mathbf{m M}$ \\
\hline 1 & F9 & $02.17 \pm 0.49$ \\
2 & CB18 & $02.93 \pm 0.51$ \\
3 & Vitamin C & $0.029 \pm 0.47$ \\
\hline
\end{tabular}

All isolates exhibited $I C_{50}$ in millimolar $(\mathrm{mM})$ range. Their results were not promising as compared to vitamin $\mathrm{C}$. This effect could stem from the absence of any functional groups capable of reduction.

\subsection{Enzyme Inhibition Activities}

The isolated compounds were also studied for their enzyme inhibition potential against AChE and GluE. The results in terms of percentage inhibition have been mentioned in Tables 4 and 5 .

Table 4. AChE inhibition activities of isolates (F9 \& CB18) at $0.5 \mathrm{mM}$ with Eserine as standard. The values represent average percentage inhibition \pm standard error (S.E.) of three repeated experiments.

\begin{tabular}{ccc}
\hline Ser. No. & Compounds & Inhibition (\%) at 0.5 mM AChE \\
\hline 1 & F9 & N.D. \\
2 & CB18 & $13.25 \pm 0.14$ \\
3 & Eserine & $91.27 \pm 1.17$ \\
\hline \multicolumn{3}{c}{ N.D. = not detected. } \\
\hline
\end{tabular}


Table 5. GluE inhibition activity of isolates (F9 \& CB18) at $0.5 \mathrm{mM}$ with Acarbose as standard. Each value represents average percentage inhibition \pm standard error (S.E.) of three repeated experiments.

\begin{tabular}{ccc}
\hline Ser. No. & Compounds & Inhibition (\%) at 0.5 $\mathbf{~ m M}$ \\
\hline 1 & F9 & $43.82 \pm 0.17$ \\
2 & CB18 & $42.35 \pm 0.19$ \\
3 & Acarbose & $92.23 \pm 0.16$ \\
\hline
\end{tabular}

Tables 3 and 4 revealed the results of enzyme inhibition activity. At the test concentration (i.e., $0.5 \mathrm{mM}$ ) CB18 depicted slight AChE inhibition activity of $13.25 \%$ in comparison to the Eserine standard that showed $91.27 \%$ enzyme inhibition. These compounds were also tested for GluE inhibition activity. The compounds F9 and CB18 with a concentration of $0.5 \mathrm{mM}$ displayed reasonable $43.82 \%$ and $42.35 \%$ enzyme inhibition activity, respectively; whereas Acarbose (standard drug) presented $92.23 \%$ inhibition.

\subsection{Molecular Docking and MD Simulations}

Molecular docking was employed to investigate the binding pose of CB18 and F9 with corresponding proteins, which were validated experimentally after reverse docking predictions. Molecular docking revealed fairly good binding affinities against AChE $(-6.6$ and $6.5 \mathrm{kcal} / \mathrm{mol})$, alpha-glucosidase $(-6.9$ and $6.2 \mathrm{kacal} / \mathrm{mol})$ and also with bacterial targets, E. coli-DHPS $(-6$ and $-5.9 \mathrm{kcal} / \mathrm{mol}$ ) and S. aureus-DHFR ( $-6.2 \mathrm{and}-6.1 \mathrm{kcal} / \mathrm{mol})$, for CB18 and $\mathbf{F} 9$ respectively. To check the all-atoms backbone stability of proteins in the presence of the corresponding ligand. MD simulations was performed to check the fluctuations in the root-mean-square-deviation (RMSD) of backbone atoms over a time period of $20 \mathrm{~ns}$ and analyzed together with co-crystalized ligand of corresponding PDB using 2D-ligplot and chimera molecular surface representation. The overall binding interaction analysis with bacterial enzymatic targets is illustrated in Figures 3 and 4.
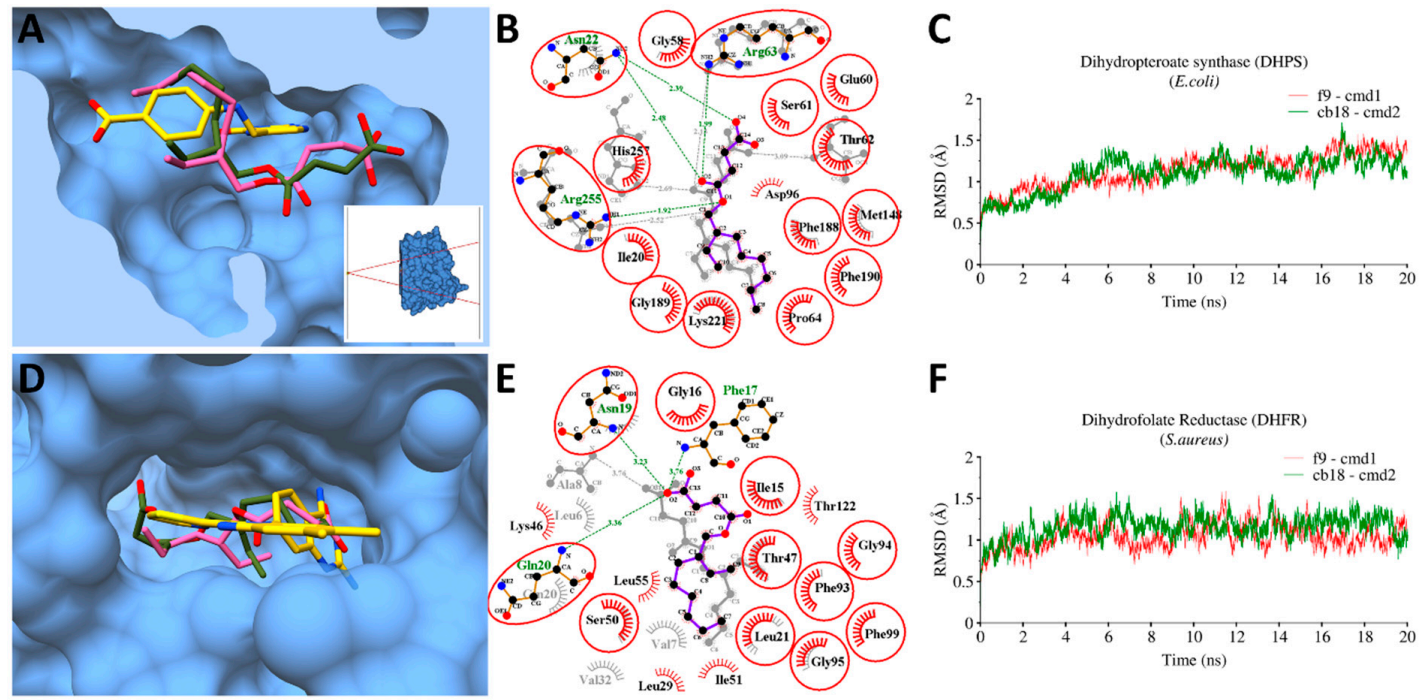

Figure 3. Molecular interactions and molecular dynamics (MD) simulations of CB18 and F9 against E. coli-Dihydropteroate synthase (DHPS) and S. aureus-Dihydrofolate Reductase (DHFR). (A) The molecular surface representation of DHPS with bound pteroic acid (gold), CB18 (pink) and F9 (green) superimposed together; (B) 2D-interaction plots with E. coli-DHPS after MD-simulations, hydrophobic interacting residues are labeled black with spiked red arc, while those interacting through H-bonds are labelled green with distance in angstrom. Conserved residues are marked with red circles; (C) root mean square deviation (RMSD) trajectory plots of E. coli-DHPS with bound CB18 (green) and F9 (red) over a period of $20 \mathrm{~ns}$. The same representations of corresponding S. aureus-DHFR with bound CB18 and $\mathbf{F 9}$ are displayed in (D-F) in the same color schemes. 

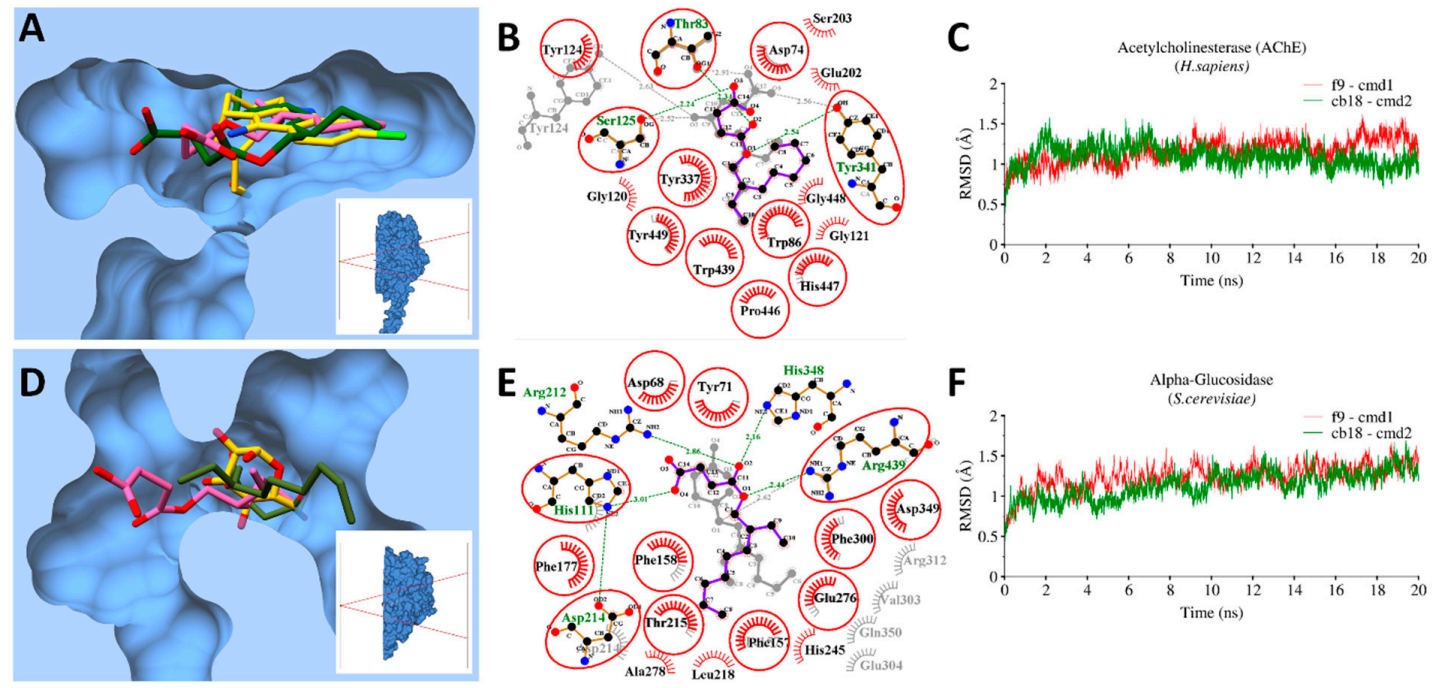

Figure 4. Molecular interactions and MD simulations of CB18 and F9 against AChE and $S$. cerevisiae- $\alpha$-glucosidase. (A) The molecular surface representation of acetylcholinesterase (AChE) with bound co-crystalized ligand (gold), CB18 (green) and F9 (pink) superimposed together; (B) 2D-interaction plots with AChE after MD-simulations, hydrophobic interacting residues are labeled black with spiked red arc, while those interacting through $\mathrm{H}$-bonds are labelled green with distance in angstrom. Conserved residues are marked with red circles; (C) RMSD trajectory plots of AChE with bound CB18 (green) and F9 (red) over a period of $20 \mathrm{~ns}$. The same representation of corresponding S. cerevisiae- $\alpha$-glucosidase with bound CB18 and F9 are displayed in (D-F) respectively in the same color schemes.

\subsubsection{Bacterial Targets}

Overall, the generated RMSD plot for E. coli-DHPS and S. aureus-DHFR complexed with CB18 and F9 were quite stable and remain converged between $\sim 0.75 \AA$. This stability was evident with the stable conformation of the ligand inside the binding pocket during the entire simulation period (Figure 3). The 3D-conformations of CB18 and F9 were found deep inside the binding pocket together with the corresponding co-crystalized pteroic acid [57] and [58] in E. coli-DHPS and S. aureus-DHFR, respectively (Figure 3A,D).

The 2D interaction analysis after $20 \mathrm{~ns}$ revealed the contribution of fumarate moiety in establishing H-bonds ( $<3 \AA$ distance), while 2-ethylhexyl and 2-ethyloctyl through hydrophobic interactions with the binding site residues of E. coli-DHPS and S. aureus-DHFR respectively. The fumarate moiety interacted through H-bonds with common residues, including Asn22, Arg63 and Arg255, whereas F9 established additional H-bonds with Thr62 and His257 (Figure 3B). Likewise, with DHFR, Asn19 and Gln20 were commonly interacted through H-bonds, while the additional H-bond was observed in F9 and CB18 with Ala8 and Phe17 residues. Apart from H-bonds, a large number of conserved hydrophobic interactions were also observed including Ile20, Gly58, Glu60, Ser61, Pro64, Met148, Phe188, Gly189, Phe190, and Lys221 in E. coli-DHPS, whereas Ile15, Gly16, Leu21, Thr47, Ser50, Phe93, Gly94, Gly95, and Phe99 in S. aureus-DHFR.

\subsubsection{Enzymatic Targets}

The RMSD trajectory plots of corresponding enzymes with bound ligands showed a similar trend, where the complexes remained converge between $0.75-1.25 \AA$ in AChE and S. cerevisiae- $\alpha$-glucosidase. Both compounds were found to have a similar binding pose deep inside the hydrophobic groove of both enzymes when superimposed on reported co-crystalized complexes [55] (Figure 4A,D). Likewise, in the interaction of CB18 and F9 with other bacterial targets (Figure 3B,E), fumarate moiety actively contributed in H-bond interactions ( $<3 \AA$ distance) with conserved residues, including Thr83, Ser125 
and Tyr341 in AChE, where F9 established one additional H-bond with Tyr124 (Figure 4B). With $\alpha$-Glucosidase, His111, Asp214, Arg439 were revealed conserve residues in establishing H-bonds with both ligands whereas CB18 established additional H-bonds with His348 and Arg212 (Figure 4E).

\subsection{MMGBSA Binding Free Energy Calculations}

To further explore the binding free energy calculations between selected proteins with CB18 and $\mathbf{F 9}$ compounds separately, MMGBSA calculations were performed. The MMGBSA total energy $\left(\Delta \mathrm{G}_{\mathrm{tol}}\right)$ was divided into molecular mechanics $\left(\Delta \mathrm{E}_{\mathrm{MM}}\right)$ and solvation energy $\left(\Delta \mathrm{G}_{\mathrm{sol}}\right)$ contributions. $\Delta \mathrm{E}_{\text {ele }}$ is further divided into van der Waals $\left(\Delta \mathrm{E}_{\mathrm{vdw}}\right)$ and electrostatic energy contributions $\left(\Delta \mathrm{E}_{\text {ele }}\right)$ while solvation energy is divided into polar $\left(\Delta G_{p}\right)$ and nonpolar $\left(\Delta G_{n p}\right)$ contributions. A total of 1000 snapshots were extracted from the whole trajectory for binding free energy calculations. The predicted total binding affinities and contributing energies are tabulated in Table 6.

Table 6. Binding affinities and contributing energies of the isolates.

\begin{tabular}{ccccccccc}
\hline $\begin{array}{c}\text { Identified } \\
\text { Targets }\end{array}$ & $\begin{array}{c}\text { Bioactive } \\
\text { Compounds }\end{array}$ & $\Delta \mathrm{E}_{\mathbf{v d w}}$ & $\Delta \mathrm{E}_{\mathbf{e l e}}$ & $\Delta \mathrm{E}_{\mathbf{M M}}$ & $\Delta \mathrm{G}_{\mathbf{p}}$ & $\Delta \mathrm{G}_{\mathbf{n p}}$ & $\Delta \mathrm{G}_{\text {sol }}$ & $\Delta \mathrm{G}_{\text {tol }}$ \\
\hline \multirow{2}{*}{ AChE } & $\mathbf{C B 1 8}$ & -40.05 & -8.67 & -48.72 & 23.89 & -3.46 & 20.43 & -28.29 \\
\cline { 2 - 8 } & $\mathbf{F 9}$ & -39.98 & -9.56 & -49.54 & 22.13 & -4.11 & 18.02 & -31.52 \\
\hline \multirow{2}{*}{ Gluco } & $\mathbf{C B 1 8}$ & -45.64 & -10.21 & -55.85 & 23.68 & -7.69 & 15.99 & -39.86 \\
\cline { 2 - 8 } & $\mathbf{F 9}$ & -43.54 & -11.33 & -54.87 & 26.39 & -6.44 & 19.95 & -34.92 \\
\hline \multirow{2}{*}{ DHPS (E. coli) } & $\mathbf{C B 1 8}$ & -24.2 & -8.27 & -32.47 & 16.41 & -2.64 & 13.77 & -18.7 \\
\cline { 2 - 8 } & $\mathbf{F 9}$ & -21 & -5.61 & -26.61 & 17.03 & -3.21 & 13.82 & -12.79 \\
\hline \multirow{2}{*}{ DHFR (S. aureus) } & $\mathbf{C B 1 8}$ & -28.44 & -5.25 & -33.69 & 20.26 & -4.32 & 15.94 & -17.75 \\
\cline { 2 - 8 } & $\mathbf{F 9}$ & -26.21 & -4.22 & -30.43 & 21.59 & -5.89 & 15.7 & -14.73 \\
\hline
\end{tabular}

The MMGBSA calculations along with molecular mechanics $\left(\triangle \mathrm{E}_{\mathrm{MM}}\right)$ and solvation energy $\left(\Delta \mathrm{G}_{\mathrm{sol}}\right)$ contributions are tabulated in Table 6 . The estimated MMGBSA values for the targets were slightly consistent with the experimental results. For instance, the MMGBSA binding free energy was very promising with both compounds, CB18 and F9 against $\alpha-\mathrm{GluE}\left(\Delta \mathrm{G}_{\mathrm{tol}}=-39.86 \mathrm{kcal} / \mathrm{mol}\right.$; $\left.\Delta \mathrm{G}_{\mathrm{tol}}=-34.92 \mathrm{kcal} / \mathrm{mol}\right)$, the results were apparent with reasonable $43.82 \%$ (CB18) and $42.35 \%$ (F9) enzyme inhibition activity with respect to Acarbose (standard drug) $(92.23 \%)$ at a concentration of $0.5 \mathrm{mM}$. While, with antibacterial potential targets, CB18 and F9 revealed lower $\Delta \mathrm{G}_{\text {tol }}$ with $E$. coli DHPS $\left(\Delta \mathrm{G}_{\mathrm{tol}}=-18.7 \mathrm{kcal} / \mathrm{mol}\right.$ and $\left.\Delta \mathrm{G}_{\mathrm{tol}}=-12.79 \mathrm{kcal} / \mathrm{mol}\right)$ and $S$. aureus DHFR $\left(\Delta \mathrm{G}_{\mathrm{tol}}=-17.75 \mathrm{kcal} / \mathrm{mol}\right.$ and $\Delta \mathrm{G}_{\mathrm{tol}}=-14.73 \mathrm{kcal} / \mathrm{mol}$ ) which were evident from less significant antibacterial activity of both compounds (CB18 and F9) against E. coli (i.e., $11.33 \%$ and $14.33 \%$ ) and S. aureus (i.e., $14 \%$ and $10 \%)$ as compared to ampicillin $(90 \%$ and $95 \%)$ at $1 \mathrm{mg} / \mathrm{mL}$, respectively. Likewise, the estimated $\Delta \mathrm{G}_{\mathrm{tol}}$ of $\mathbf{C B 1 8}$ and $\mathbf{F 9}$ with AChE also showed higher binding energy $\left(\Delta \mathrm{G}_{\mathrm{tol}}=-28.29 \mathrm{kcal} / \mathrm{mol}\right.$ and $\left.\Delta \mathrm{G}_{\mathrm{tol}}=-31.52 \mathrm{kcal} / \mathrm{mol}\right)$.

\section{Conclusions}

Through bioassay direction, two maleates were isolated from P. cretica and their structures were elucidated. Target potentials were evaluated by reverse docking and biological potentials of the isolates were measured for best-targeted potentials. The results show that the isolates are moderately active against all tested activities. Consequently, it can be said that the isolates have poly-pharmacological potentials. Further study is required to fully explore this plant species. 
Supplementary Materials: The following are available online at http://www.mdpi.com/2076-3921/8/7/231/s1, Table S1. Detailed absorption, distribution, metabolism, toxicity and excretion in silico assessment.

Author Contributions: Conceptualization, I.A., M.U.M. and S.A.; Formal analysis, F.S., R.M., S.M., M.T.J.K., Z.-u.-D.K., M.A. and M.S.A.; Investigation, R.M.; Methodology, F.S., M.T.J.K., Z.-u.-D.K., M.A. and S.A.; Resources, M.S.A., I.A. and M.U.M.; Supervision, S.A.; Validation, R.M.; Visualization, F.S.; Writing-original draft, F.S. and M.U.M.; Writing-review \& editing, M.T.J.K., M.F. and S.A.

Funding: This research received no external funding.

Conflicts of Interest: The authors declare no conflict of interest.

\section{References}

1. Raghavendra, M.; Satish, S.; Raveesha, K. Phytochemical analysis and antibacterial activity of Oxalis corniculata; a known medicinal plant. Myscience 2006, 1, 72-78.

2. Şahin, F.; Karaman, I.; Güllüce, M.; Öğütçü, H.; Şengül, M.; Adıgüzel, A.; Öztürk, S.; Kotan, R. Evaluation of antimicrobial activities of Satureja hortensis L. J. Ethnopharmacol. 2003, 87, 61-65. [CrossRef]

3. Newman, D.J.; Cragg, G.M. Natural Products as Sources of New Drugs from 1981 to 2014. J. Nat. Prod. 2016, 79, 629-661. [CrossRef] [PubMed]

4. Zhang, L.; Rothfels, C.J.; Ebihara, A.; Schuettpelz, E.; Le Péchon, T.; Kamau, P.; He, H.; Zhou, X.-M.; Prado, J.; Field, A.; et al. A global plastid phylogeny of the brake fern genus Pteris (Pteridaceae) and related genera in the Pteridoideae. Cladistics 2015, 31, 406-423. [CrossRef]

5. Pratibha, K.; Otaghvari, A.M.; Govindapyari, H.; Bahuguna, Y.M.; Uniyal, P. Some ethno-medicinally important pteridophytes of India. Int. J. Med. Arom. Plants 2011, 1, 18-22.

6. Imperato, F. Luteolin 8-C-rhamnoside-7-O-rhamnoside from Pteris cretica. Phytochemistry 1994, 37, 589-590. [CrossRef]

7. Saleem, F.; Khan, M.T.J.; Saleem, H.; Azeem, M.; Ahmed, S.; Shahid, N.; Altaf, H. Phytochemical, antimicrobial and antioxidant activities of Pteris cretica L. (Pteridaceae) extracts. Acta. Pol. Pharm. 2016, 73, 1397-1403. [PubMed]

8. Diopan, V.; Babula, P.; Shestivska, V.; Adam, V.; Zemlicka, M.; Dvorska, M.; Hubalek, J.; Trnkova, L.; Havel, L.; Kizek, R. Electrochemical and spectrometric study of antioxidant activity of pomiferin, isopomiferin, osajin and catalposide. J. Pharm. Biomed. Anal. 2008, 48, 127-133. [CrossRef]

9. Wondrak, G.T.; Villeneuve, N.F.; Lamore, S.D.; Bause, A.S.; Jiang, T.; Zhang, D.D. The cinnamon-derived dietary factor cinnamic aldehyde activates the Nrf2-dependent antioxidant response in human epithelial colon cells. Molecules 2010, 15, 3338-3355. [CrossRef]

10. Adams, R.; Craig, P.; Parsons, O. Neuropsychology of dementia. Neurol. Clin. 1986, 4, 387-404. [CrossRef]

11. Orhan, I.; Şener, B.; Choudhary, M.; Khalid, A. Acetylcholinesterase and butyrylcholinesterase inhibitory activity of some Turkish medicinal plants. J. Ethnopharmacol. 2004, 91, 57-60. [CrossRef] [PubMed]

12. Hung, C.L.; Chen, C.C. Computational approaches for drug discovery. Drug Dev. Res. 2014, 75, $412-418$. [CrossRef] [PubMed]

13. Katsila, T.; Spyroulias, G.A.; Patrinos, G.P.; Matsoukas, M.T. Computational approaches in target identification and drug discovery. Comput. Struct. Biotechnol. J. 2016, 14, 177-184. [CrossRef] [PubMed]

14. Macalino, S.J.; Gosu, V.; Hong, S.; Choi, S. Role of computer-aided drug design in modern drug discovery. Arch. Pharm. Res. 2015, 38, 1686-1701. [CrossRef] [PubMed]

15. Xu, X. New concepts and approaches for drug discovery based on traditional Chinese medicine. Drug Discov. Today 2006, 3, 247-253. [CrossRef]

16. Xiang, M.; Cao, Y.; Fan, W.; Chen, L.; Mo, Y. Computer-aided drug design: Lead discovery and optimization. Comb. Chem. High Throughput Screen. 2012, 15, 328-337. [CrossRef] [PubMed]

17. Ramström, O.; Lehn, J.-M. Drug discovery by dynamic combinatorial libraries. Nat. Rev. Drug Discov. 2002, 1, 26. [CrossRef]

18. Lehn, J.-M.; Eliseev, A.V. Dynamic combinatorial chemistry. Science 2001, 291, 2331-2332. [CrossRef]

19. Terrett, N.K.; Gardner, M.; Gordon, D.W.; Kobylecki, R.J.; Steele, J. Combinatorial synthesis-the design of compound libraries and their application to drug discovery. Tetrahedron 1995, 51, 8135-8173. [CrossRef]

20. Klebe, G. Virtual ligand screening: Strategies, perspectives and limitations. Drug Discov. Today 2006, 11, 580-594. [CrossRef] 
21. Ma, X.H.; Jia, J.; Zhu, F.; Xue, Y.; Li, Z.R.; Chen, Y.Z. Comparative analysis of machine learning methods in ligand-based virtual screening of large compound libraries. Comb. Chem. High Throughput Screen. 2009, 12, 344-357. [CrossRef] [PubMed]

22. Waszkowycz, B. Structure-based approaches to drug design and virtual screening. Curr. Opin. Drug Discov. Devel. 2002, 5, 407-413. [PubMed]

23. Cheng, T.; Li, Q.; Zhou, Z.; Wang, Y.; Bryant, S.H. Structure-based virtual screening for drug discovery: A problem-centric review. AAPS J. 2012, 14, 133-141. [CrossRef] [PubMed]

24. Ekins, S.; Mestres, J.; Testa, B. In silico pharmacology for drug discovery: Methods for virtual ligand screening and profiling. Br. J. Pharmacol. 2007, 152, 9-20. [CrossRef] [PubMed]

25. Kumar, A.; Zhang, K.Y. Hierarchical virtual screening approaches in small molecule drug discovery. Methods 2015, 71, 26-37. [CrossRef] [PubMed]

26. Lavecchia, A.; Di Giovanni, C. Virtual screening strategies in drug discovery: A critical review. Cur. Med. Chem. 2013, 20, 2839-2860. [CrossRef]

27. Hui-fang, L.; Qing, S.; Jian, Z.; Wei, F. Evaluation of various inverse docking schemes in multiple targets identification. J. Mol. Graph. Model. 2010, 29, 326-330. [CrossRef]

28. Kharkar, P.S.; Warrier, S.; Gaud, R.S. Reverse docking: A powerful tool for drug repositioning and drug rescue. Future Med. Chem. 2014, 6, 333-342. [CrossRef]

29. Böttcher, T.; Pitscheider, M.; Sieber, S.A. Natural products and their biological targets: Proteomic and metabolomic labeling strategies. Angew. Chem Int. Ed. 2010, 49, 2680-2698. [CrossRef]

30. Cheng, K.W.; Wong, C.C.; Wang, M.; He, Q.Y.; Chen, F. Identification and characterization of molecular targets of natural products by mass spectrometry. Nucleic Acids Res. 2010, 29, 126-155. [CrossRef]

31. Huang, C.-M.; Elmets, C.A.; De-chu, C.T.; Li, F.; Yusuf, N. Proteomics reveals that proteins expressed during the early stage of Bacillus anthracis infection are potential targets for the development of vaccines and drugs. Genom. Proteom. Bioinform. 2004, 2, 143-151. [CrossRef]

32. Li, H.; Zheng, M.; Liu, X.; Jiang, H. Computational Approach for Drug Target Identification. Chem. Genom. 2012, 279.

33. Liu, X.; Ouyang, S.; Yu, B.; Liu, Y.; Huang, K.; Gong, J.; Zheng, S.; Li, Z.; Li, H.; Jiang, H. PharmMapper server: A web server for potential drug target identification using pharmacophore mapping approach. Nucleic Acids Res. 2010, 38, W609-W614. [CrossRef] [PubMed]

34. Kinnings, S.L.; Jackson, R.M. ReverseScreen3D: A structure-based ligand matching method to identify protein targets. J. Chem. Inf. Model. 2011, 51, 624-634. [CrossRef] [PubMed]

35. Chen, Y.; Ung, C. Prediction of potential toxicity and side effect protein targets of a small molecule by a ligand-protein inverse docking approach. J. Mol. Graph. Model. 2001, 20, 199-218. [CrossRef]

36. Li, H.; Gao, Z.; Kang, L.; Zhang, H.; Yang, K.; Yu, K.; Luo, X.; Zhu, W.; Chen, K.; Shen, J.; et al. TarFisDock: A web server for identifying drug targets with docking approach. Nucleic Acids Res. 2006, 34, W219-W224. [CrossRef] [PubMed]

37. Wang, J.-C.; Chu, P.-Y.; Chen, C.-M.; Lin, J.-H. idTarget: A web server for identifying protein targets of small chemical molecules with robust scoring functions and a divide-and-conquer docking approach. Nucleic Acids Res. 2012, 40, W393-W399. [CrossRef]

38. Wang, L.; Ma, C.; Wipf, P.; Liu, H.; Su, W.; Xie, X.-Q. TargetHunter: An in silico target identification tool for predicting therapeutic potential of small organic molecules based on chemogenomic database. AAPS J. 2013, 15, 395-406. [CrossRef]

39. Zheng, R.; Chen, T.-S.; Lu, T. A comparative reverse docking strategy to identify potential antineoplastic targets of tea functional components and binding mode. Int. J. Mol. Sci. 2011, 12, 5200-5212. [CrossRef]

40. Bhattacharjee, B.; Vijayasarathy, S.; Karunakar, P.; Chatterjee, J. Comparative reverse screening approach to identify potential anti-neoplastic targets of saffron functional components and binding mode. Asian Pac. J. Cancer Prev. 2012, 13, 5605-5611. [CrossRef]

41. Bhattacharjee, B.; Chatterjee, J. Identification of proapoptopic, anti-inflammatory, anti-proliferative, anti-invasive and anti-angiogenic targets of essential oils in cardamom by dual reverse virtual screening and binding pose analysis. Asian Pac. J. Cancer Prev. 2013, 14, 3735-3742. [CrossRef] [PubMed]

42. Kumar, R.P.; Manoj, M.; Kush, A.; Annadurai, R. In silico approach of azadirachtin binding with actins. Insect Biochem. Mol. Biol. 2007, 37, 635-640. [CrossRef] [PubMed] 
43. Kiss, R.; Szalai, F.; Sandor, M. Mcule.com: A public web service for drug discovery. Abstr. Pap. Am. Chem. Soc. 2012, 243. [CrossRef]

44. Cheng, F.; Li, W.; Zhou, Y.; Shen, J.; Wu, Z.; Liu, G.; Lee, P.W.; Tang, Y. admetSAR: A comprehensive source and free tool for assessment of chemical ADMET properties. J. Chem. Inf. Model. 2012, 52, 3099-3105. [CrossRef] [PubMed]

45. Liu, T.; Lin, Y.; Wen, X.; Jorissen, R.N.; Gilson, M.K. BindingDB: A web-accessible database of experimentally determined protein-ligand binding affinities. Nucleic Acids Res. 2006, 35, D198-D201. [CrossRef] [PubMed]

46. Wishart, D.S.; Knox, C.; Guo, A.C.; Shrivastava, S.; Hassanali, M.; Stothard, P.; Chang, Z.; Woolsey, J. DrugBank: A comprehensive resource for in silico drug discovery and exploration. Nucleic Acids Res. 2006, 34, D668-D672. [CrossRef] [PubMed]

47. Gao, Z.; Li, H.; Zhang, H.; Liu, X.; Kang, L.; Luo, X.; Zhu, W.; Chen, K.; Wang, X.; Jiang, H. PDTD: A web-accessible protein database for drug target identification. BMC Bioinform. 2008, 9, 104. [CrossRef] [PubMed]

48. Wang, Y.; Bolton, E.; Dracheva, S.; Karapetyan, K.; Shoemaker, B.A.; Suzek, T.O.; Wang, J.; Xiao, J.; Zhang, J.; Bryant, S.H. An overview of the PubChem BioAssay resource. Nucleic Acids Res. 2009, 38, D255-D266. [CrossRef]

49. Mangal, M.; Sagar, P.; Singh, H.; Raghava, G.P.; Agarwal, S.M. NPACT: Naturally occurring plant-based anti-cancer compound-activity-target database. Nucleic Acids Res. 2012, 41, D1124-D1129. [CrossRef] [PubMed]

50. Ye, H.; Ye, L.; Kang, H.; Zhang, D.; Tao, L.; Tang, K.; Liu, X.; Zhu, R.; Liu, Q.; Chen, Y.Z.; et al. HIT: Linking herbal active ingredients to targets. Nucleic Acids Res. 2010, 39, D1055-D1059. [CrossRef] [PubMed]

51. Sarker, S.D.; Nahar, L.; Kumarasamy, Y. Microtitre plate-based antibacterial assay incorporating resazurin as an indicator of cell growth, and its application in the in vitro antibacterial screening of phytochemicals. Methods 2007, 42, 321-324. [CrossRef] [PubMed]

52. Taha, M.; Ismail, N.H.; Khan, A.; Shah, S.A.A.; Anwar, A.; Halim, S.A.; Fatmi, M.Q.; Imran, S.; Rahim, F.; Khan, K.M. Synthesis of novel derivatives of oxindole, their urease inhibition and molecular docking studies. Bioorg. Med. Chem. Lett. 2015, 25, 3285-3289. [CrossRef] [PubMed]

53. Chapdelaine, P.; Tremblay, R.R.; Dube, J. P-Nitrophenol-alpha-D-glucopyranoside as substrate for measurement of maltase activity in human semen. Clin. Chem. 1978, 24, 208-211. [PubMed]

54. Trott, O.; Olson, A.J. AutoDock Vina: Improving the speed and accuracy of docking with a new scoring function, efficient optimization, and multithreading. J. Comput. Chem. 2010, 31, 455-461. [CrossRef] [PubMed]

55. Nachon, F.; Carletti, E.; Ronco, C.; Trovaslet, M.; Nicolet, Y.; Jean, L.; Renard, P.-Y. Crystal structures of human cholinesterases in complex with huprine $\mathrm{W}$ and tacrine: Elements of specificity for anti-Alzheimer's drugs targeting acetyl-and butyryl-cholinesterase. Biochem. J. 2013, 453, 393-399. [CrossRef] [PubMed]

56. Schwede, T.; Kopp, J.; Guex, N.; Peitsch, M.C. SWISS-MODEL: An automated protein homology-modeling server. Nucleic Acids Res. 2003, 31, 3381-3385. [CrossRef] [PubMed]

57. Dennis, M.L.; Lee, M.D.; Harjani, J.R.; Ahmed, M.; DeBono, A.J.; Pitcher, N.P.; Wang, Z.C.; Chhabra, S.; Barlow, N.; Rahmani, R.; et al. 8-Mercaptoguanine Derivatives as Inhibitors of Dihydropteroate Synthase. Chem. Eur. J. 2018, 24, 1922-1930. [CrossRef] [PubMed]

58. Lam, T.; Hilgers, M.T.; Cunningham, M.L.; Kwan, B.P.; Nelson, K.J.; Brown-Driver, V.; Ong, V.; Trzoss, M.; Hough, G.; Shaw, K.J.; et al. Structure-based design of new dihydrofolate reductase antibacterial agents: 7-(benzimidazol-1-yl)-2,4-diaminoquinazolines. J. Med. Chem. 2014, 57, 651-668. [CrossRef] [PubMed]

59. Ahmed, B.; Ali Ashfaq, U.; Usman Mirza, M. Medicinal plant phytochemicals and their inhibitory activities against pancreatic lipase: Molecular docking combined with molecular dynamics simulation approach. Nat. Pro. Res. 2018, 32, 1123-1129. [CrossRef]

60. Ferdous, S.; Mirza, M.U.; Saeed, U. Docking studies reveal phytochemicals as the long searched anticancer drugs for breast cancer. Int. J. Comp. Appl. 2013, 67, 1-5. [CrossRef]

61. Yousuf, Z.; Iman, K.; Iftikhar, N.; Mirza, M.U. Structure-based virtual screening and molecular docking for the identification of potential multi-targeted inhibitors against breast cancer. Breast Cancer (Dove Med. Press) 2017, 9, 447-459. [CrossRef] [PubMed] 
62. Pettersen, E.F.; Goddard, T.D.; Huang, C.C.; Couch, G.S.; Greenblatt, D.M.; Meng, E.C.; Ferrin, T.E. UCSF Chimera-A visualization system for exploratory research and analysis. J. Comput. Chem. 2004, 25, 1605-1612. [CrossRef] [PubMed]

63. Case, D.A.; Cheatham, T.E., III; Darden, T.; Gohlke, H.; Luo, R.; Merz, K.M., Jr.; Onufriev, A.; Simmerling, C.; Wang, B.; Woods, R.J. The Amber biomolecular simulation programs. J. Comput. Chem. 2005, 26, 1668-1688. [CrossRef] [PubMed]

64. Iman, K.; Mirza, M.U.; Mazhar, N.; Vanmeert, M.; Irshad, I.; Kamal, M.A. In silico Structure-based Identification of Novel Acetylcholinesterase Inhibitors Against Alzheimer's Disease. CNS Neurol. Disord. Drug Targets 2018, 17, 54-68. [CrossRef]

65. Roe, D.R.; Cheatham, T.E., III. PTRAJ and CPPTRAJ: Software for processing and analysis of molecular dynamics trajectory data. J. Chem. Theory Comput. 2013, 9, 3084-3095. [CrossRef]

66. Gohlke, H.; Kiel, C.; Case, D.A. Insights into protein-protein binding by binding free energy calculation and free energy decomposition for the Ras-Raf and Ras-RalGDS complexes. J. Mol. Biol. 2003, 330, 891-913. [CrossRef]

67. Hayes, J.M.; Archontis, G. MM-GB (PB) SA calculations of protein-ligand binding free energies. In Molecular Dynamics-Studies of Synthetic and Biological Macromolecules; Wang, L., Ed.; InTech: Rijeka, Croatia, 2012.

68. Herbst, R.S. Review of epidermal growth factor receptor biology. Int. J. Radiat. Oncol. Biol. Phys. 2004, 59, S21-S26. [CrossRef] [PubMed]

69. Ciardiello, F. Epidermal growth factor receptor tyrosine kinase inhibitors as anticancer agents. Drugs 2000, 60, 25-32. [CrossRef]

70. Lai, C.-J.; Bao, R.; Tao, X.U.; Wang, J.; Atoyan, R.; Qu, H.; Wang, D.G.; Yin, L.; Samson, M.; Forrester, J.; et al. CUDC-101, a multitargeted inhibitor of histone deacetylase, epidermal growth factor receptor, and human epidermal growth factor receptor 2, exerts potent anticancer activity. Can. Res. 2010, 70, 3647-3656. [CrossRef]

71. Tamm, I.; Wang, Y.; Sausville, E.; Scudiero, D.A.; Vigna, N.; Oltersdorf, T.; Reed, J.C. IAP-family protein survivin inhibits caspase activity and apoptosis induced by Fas (CD95), Bax, caspases, and anticancer drugs. Can. Res. 1998, 58, 5315-5320.

72. Stewart, Z.A.; Westfall, M.D.; Pietenpol, J.A. Cell-cycle dysregulation and anticancer therapy. Trends Pharmacol. Sci. 2003, 24, 139-145. [CrossRef]

73. Sanchez-Martinez, C.; Gelbert, L.M.; Lallena, M.J.; de Dios, A. Cyclin dependent kinase (CDK) inhibitors as anticancer drugs. Bioorg. Med. Chem. Lett. 2015, 25, 3420-3435. [CrossRef] [PubMed]

74. Rakoff-Nahoum, S. Cancer Issue: Why cancer and inflammation? Yale J. Biol. Med. 2006, 79, 123. [PubMed]

75. Gupta, S.C.; Kim, J.H.; Prasad, S.; Aggarwal, B.B. Regulation of survival, proliferation, invasion, angiogenesis, and metastasis of tumor cells through modulation of inflammatory pathways by nutraceuticals. Cancer Metastasis Rev. 2010, 29, 405-434. [CrossRef] [PubMed]

76. Kaminska, B. MAPK signalling pathways as molecular targets for anti-inflammatory therapy—from molecular mechanisms to therapeutic benefits. Biochim. Biophys. Acta. Prot. Proteom. 2005, 1754, 253-262. [CrossRef] [PubMed]

77. Yadav, D.K.; Meena, A.; Srivastava, A.; Chanda, D.; Khan, F.; Chattopadhyay, S. Development of QSAR model for immunomodulatory activity of natural coumarinolignoids. Drug Des. Devel. Ther. 2010, 4, 173.

78. Hardy, J.; Allsop, D. Amyloid deposition as the central event in the aetiology of Alzheimer's disease. Trends Pharmacol. Sci. 1991, 12, 383-388. [CrossRef]

79. Ghosh, A.K.; Brindisi, M.; Tang, J. Developing $\beta$-secretase inhibitors for treatment of Alzheimer's disease. J. Neurochem. 2012, 120, 71-83. [CrossRef]

80. Hoozemans, J.; Rozemuller, J.; Van Haastert, E.; Veerhuis, R.; Eikelenboom, P. Cyclooxygenase-1 and-2 in the different stages of Alzheimer's disease pathology. Curr. Pharm. Des. 2008, 14, 1419-1427. [CrossRef]

81. Rafii, M.S.; Aisen, P.S. Advances in Alzheimer's disease drug development. BMC Med. 2015, 13, 62. [CrossRef]

82. Ploia, C.; Antoniou, X.; Sclip, A.; Grande, V.; Cardinetti, D.; Colombo, A.; Canu, N.; Benussi, L.; Ghidoni, R.; Forloni, G.; et al. JNK plays a key role in tau hyperphosphorylation in Alzheimer's disease models. J. Alzheimers Dis. 2011, 26, 315-329. [CrossRef] [PubMed]

83. Wang, J.Z.; Grundke-Iqbal, I.; Iqbal, K. Kinases and phosphatases and tau sites involved in Alzheimer neurofibrillary degeneration. Eur. J. Neurosci. 2007, 25, 59-68. [CrossRef] [PubMed] 
84. Inestrosa, N.C.; Alvarez, A.; Perez, C.A.; Moreno, R.D.; Vicente, M.; Linker, C.; Casanueva, O.I.; Soto, C.; Garrido, J. Acetylcholinesterase accelerates assembly of amyloid- $\beta$-peptides into Alzheimer's fibrils: Possible role of the peripheral site of the enzyme. Neuron 1996, 16, 881-891. [CrossRef]

85. Tsurkan, L.G.; Hatfield, M.J.; Edwards, C.C.; Hyatt, J.L.; Potter, P.M. Inhibition of human carboxylesterases hCE1 and hiCE by cholinesterase inhibitors. Chem. Biol. Interact. 2013, 203, 226-230. [CrossRef] [PubMed]

86. Robert Norman Jones, G. The Alzheimer pandemic: Is paracetamol to blame? Inflamm. Allergy Drug Targets 2014, 13, 2-14. [CrossRef]

87. Tobinick, E.; Gross, H.; Weinberger, A.; Cohen, H. TNF-alpha modulation for treatment of Alzheimer's disease: A 6-month pilot study. Med. Gen. Med. 2006, 8, 25.

88. Heckman, P.; Wouters, C.; Prickaerts, J. Phosphodiesterase inhibitors as a target for cognition enhancement in aging and Alzheimer's disease: A translational overview. Curr. Pharm. Des. 2015, 21, 317-331. [CrossRef]

(C) 2019 by the authors. Licensee MDPI, Basel, Switzerland. This article is an open access article distributed under the terms and conditions of the Creative Commons Attribution (CC BY) license (http://creativecommons.org/licenses/by/4.0/). 